\title{
Chlorophyll a fluorescence as indicative of the salt stress on Brassica napus L.
}

\section{Marcos Antonio Bacarin ${ }^{1, *}$, Sidnei Deuner ${ }^{1, \dagger}$, Fabio Sergio Paulino da Silva ${ }^{1}$, Daniela Cassol', Diolina Moura Silva²}

\footnotetext{
${ }^{1}$ Departamento de Botânica, Instituto de Biologia, Universidade Federal de Pelotas, 96010-900, Pelotas-RS, Brasil

${ }^{2}$ Departamento de Ciências Biológicas, Universidade Federal do Espírito Santo, 29075-910, Vitória-ES, Brasil.

*Corresponding author: phone: (+55) 53 32757336; fax: (+55) 53 32737169, e-mail: bacarin@ufpel.edu.br. Present address: Embrapa Cerrados - CPAC, BR 020 Km 18, 73310-970 - Brasília, DF - Brazil

Received: 27 September 2011; Accepted:04 February 2012
}

\begin{abstract}
The effects of salinity stress on chlorophyll fluorescence and the growth of Brassica napus $L$ were investigated. The chlorophyll a fluorescence transient were recorded and analyzed according to the JIP-test which can quantify PSII performance. Salt stress resulted in decreased leaf area and dry matter compared with the control treatment $(0 \mathrm{mM} \mathrm{NaCl})$. The most pronounced effects of salt stress were observed with $200 \mathrm{mM} \mathrm{NaCl}$, and the hybrids displayed different levels of sensitivity to stress. The Performance Index $\left(\mathrm{Pl}_{\mathrm{ABS}}\right)$ was the most sensitive parameter to salt stress, which suggests that this parameter can be used to screen genotypes for salt tolerance.
\end{abstract}

Keywords: Canola; growth; JIP-Test, salt stress; spring rapessed oil.

Abbreviations: ABS, absorption of light energy; Chl, chlorophyll; ET, conversion of excitation energy to electron transport (ET); $\mathrm{ET}_{\mathrm{d}} / \mathrm{ABS}$, electron transport activity; $\mathrm{F}_{0}, \mathrm{~F}_{\mathrm{v}}$, and $\mathrm{F}_{\mathrm{M}}$ - minimal, variable and maximum Chl fluorescence of PSIl in the dark adapted state; $F_{V} / F_{M}=\phi_{P_{0}}=T_{R} / A B S$, maximum efficiency of PSIl photochemistry; $F_{0}{ }^{\prime}, F_{V}$ ' and $F_{M}{ }^{\prime}$ - minimal, variable and maximum Chl fluorescence in the light adapted state; $F_{\mathrm{v}}{ }^{\prime} / F_{\mathrm{M}}$ ', efficiency of excitation capture by open PSIl reaction centers; FW, fresh weight; $\mathrm{PI}_{A B S}$, Performance Index; PSII, photosystem II; $Q_{A}$, electron acceptor of PSIl; qP, photochemical quenching coefficient; RC/ABS, ratio of reaction centers and the absorbance; TR, trapping of excitation energy; $\phi_{P S I}$, actual PSII efficiency; $\phi_{E_{0}}=\mathrm{ET}_{0} / \mathrm{ABS}$, quantum yield of electron transport; $\phi_{D 0}$, quantum yield of dissipation; $\Psi_{0}=E T_{0} / T_{0}$, yield of electron transport per trapped exciton; PAR, photosynthetic active radiation.

\section{INTRODUCTION}

Spring rapessed oil (canola) is an important crop in many countries. Currently, the dominant species is Brassica napus $L$. The seed typically has an oil content ranging from 35 to $45 \%$ and a minimum protein content of $35 \%$. Canola is a form of rapeseed that has less than $2 \%$ erucic acid in its oil and less than $30 \mu$ moles of total glucosinolates in its seed meal (Kris-Etherton et al., 2000).
Stress factors, such as high or low temperatures, drought, high light and salinity can alter many physiological processes and suppress the photosynthetic activity of plants. Soil salinity is a major constraint limiting agriculture productivity (Zhu, 2001). Salt stress has been reported to cause an inhibition of growth and development and reductions in photosynthesis, respiration and protein synthesis in sensitive species (Panda et al., 2006). Salt ion toxicity causes numerous deleterious effects in plants by promoting the denaturation of cytosolic 
enzymes and facilitating the formation of reactive oxygen species that can damage membranes and proteins (Zhu, 2001). The decrease in photosynthetic activity frequently observed under salt stress may be due to limitations in photosynthetic electron transport and partial stomatal closure (Flexas et al., 2004). Although the effects of salt stress on photosynthesis have been studied intensively, the mechanisms of inhibition of photosynthesis by salt stress remain unclear (Munns and Tester, 2008). Many studies have investigated the effect of salt stress in different plant species and cultivars, including maize (Azevedo Neto et al., 2004), dwarf-cashew (Abreu et al., 2008), cowpea (Maia et al., 2010), faba bean (Tavakkoli et al., 2010), Silver buffaloberry (Qin et al., 2010), among others. But the effects on chlorophyll fluorescence parameters in plants are not clear. In both salt-sensitive and salt-tolerant of Chickpea seedling the salt stress affect $F_{\mathrm{V}} / F_{\mathrm{M}}, \phi_{\text {PSII }}, \mathrm{qP}, \mathrm{F}_{0}$, and $F_{M}$ (Eyidogan and Tufan, 2007). However, others authors reported that salinity does not affect chlorophyll fluorescence (Redondo-Gómez et al., 2007). Measurement of chlorophyll a fluorescence, a non-invasive method, is widely used for monitoring and screening different species and genotypes for stress resistance or tolerance (Percival et al., 2003). The objective of the present study was evaluated the effect of salt stress in five hybrids of canola by determination the growth of the plant and the fluorescence of chlorophyll $a$.

\section{MATERIALS AND METHODS}

Growth conditions and treatments: The seeds of Brassica napus L. var. oleifera (hybrids Hyola 43, Hyola 61, Hyola 401, Hyola 420 and Hyola 432 from Celena Alimentos S/A - some characteristics were presented in Table 1) were germinated directly in sand, and the plants were grown in 5-liter pots. Plants were grown in a greenhouse during September-January in 2008-2009. The environmental conditions during the growth were: air temperature $25-30^{\circ} \mathrm{C}$ during the day and $15^{\circ} \mathrm{C}$ roughly in the night. The PAR at 9 a.m. was $450-500 \mu \mathrm{mol} \mathrm{m} \mathrm{m}^{-2} \mathrm{~s}^{-1}$. Immediately after sowing, all pots were randomly divided into four groups, and we started the application of the salt solution; one group was grown in the nutrient solution Hoagland (Hoagland and Arnon, 1950) as the non-salt stressed (control), while the others were grown in complete nutrient solution plus 50 , 100 and $200 \mathrm{mM} \mathrm{NaCl}$ as the salt stress treatments.
Table 1. The most important characteristics of the hybrids used in experiment

\begin{tabular}{|c|c|c|c|c|c|}
\hline \multirow[b]{2}{*}{ Characteristics } & \multicolumn{5}{|c|}{ Hybrids } \\
\hline & Hyola 43 & Hyola 61 & Hyola 401 & Hyola 420 & Hyola 432 \\
\hline $\begin{array}{c}\text { Emergence to } \\
\text { beginning of } \\
\text { flowering (days) }\end{array}$ & 53 to 77 & 60 to 77 & 44 to 74 & 64 to 70 & 47 to 73 \\
\hline $\begin{array}{c}\text { Plant cycle } \\
\text { - number of } \\
\text { days from plant } \\
\text { emergence to } \\
\text { harvest } \\
\end{array}$ & $\begin{array}{c}123 \\
\text { to } 155\end{array}$ & $\begin{array}{c}127 \\
\text { to } 139\end{array}$ & $\begin{array}{c}107 \text { to } \\
135\end{array}$ & $\begin{array}{c}116 \\
\text { to } 150\end{array}$ & $\begin{array}{c}119 \\
\text { to } 134\end{array}$ \\
\hline Plant height (cm) & $\begin{array}{c}78 \\
\text { to } 129 \\
\end{array}$ & $\begin{array}{c}105 \\
\text { to } 134\end{array}$ & $\begin{array}{c}86 \\
\text { to } 126 \\
\end{array}$ & $\begin{array}{c}116 \\
\text { to } 130\end{array}$ & $\begin{array}{c}89 \\
\text { to } 124\end{array}$ \\
\hline
\end{tabular}

Chlorophyll content, leaf area and dry weight: Chlorophyll content was measured 48 DAS, and we used a chlorophyll meter (CL-01, Hansatech Instruments, Kings Lynn, UK) to measure the middle region of the youngest mature leaf. The values were expressed as the "chlorophyll index" (Cassol et al., 2008). Leaf area, using a area meter (LI-3100, Licor, Lincoln, NE 68504 USA), and total dry weight were measured $48 \mathrm{DAS}$. The seeds yield was estimated when they had uniformly matured (100 DAS), and express as fresh weight per plant.

Polyphasic Chl a fluorescence transients: Polyphasic $\mathrm{Chl}$ a fluorescence transients were measured with a direct fluorometer (Handy PEA, Hansatech Instruments, Kings Lynn, UK) at 48 DAS. All fluorescence measurements were taken in the middle part of the plant, in fully expanded leaves, with 10 replicates for each treatment (salinity/hybrids). Leaf samples were illuminated with continuous red light (650 nm peak wavelength) after 30 min in dark-adaptation. All measurements were taken using a saturating pulse of $3.000 \mu \mathrm{mol} \mathrm{m}{ }^{-2} \mathrm{~s}^{-1}$ for $1 \mathrm{~s}$. Upon irradiation, dark-adapted photosynthetic samples exhibit a fast fluorescence rise from the initial fluorescence intensity $F_{0}$ to a maximal intensity $\mathrm{F}_{\mathrm{M}}$ (Lazár, 2006). The fluorescence intensity at $50 \mu \mathrm{s}$ was considered to be $F_{0}$, initial (minimal) fluorescence. The JIP test (Strasser and Strasser, 1995; Strasser and Tsimilli-Michael, 2000; Strasser et al., 2000, 2004) was used to analyze each $\mathrm{Chl}$ fluorescence transient. The Performance Index $\left(\mathrm{Pl}_{A B S}\right)$ was one of the $\mathrm{Chl}$ fluorescence parameters that provided useful and quantitative information about the state of plants and their vitality (Strasser et al., 2000).

The $\mathrm{Pl}_{\mathrm{ABS}}$ is a combined measure of three partial performances, namely those related to the amount of 
photosynthetic reaction centers $(\mathrm{RC} / \mathrm{ABS})$, the maximal energy flux that reaches the PSIl reaction center $\left(\mathrm{TR}_{0}\right)$, and the electron transport at the onset of illumination $\left(\mathrm{ET}_{0}\right)$.

$\mathrm{PI}_{\mathrm{ABS}}=\frac{\mathrm{RC}}{\mathrm{ABS}} \cdot \frac{\varphi_{\mathrm{P}_{\mathrm{o}}}}{1-\varphi_{\mathrm{P}_{0}}} \cdot \frac{\psi_{0}}{1-\psi_{\mathrm{o}}}=\frac{\mathrm{RC}}{\mathrm{ABS}} \cdot \frac{\mathrm{TR}_{0}}{\mathrm{DI}_{0}} \cdot \frac{\mathrm{ET}_{0}}{\mathrm{TR}_{0}-\mathrm{ET}_{0}}$

where $\mathrm{RC} / \mathrm{ABS}$ is the ratio of reaction centers and the absorbance (the concentration of reaction centers per chlorophyll), $\phi_{\mathrm{P}} /\left(1-\phi_{\mathrm{P}_{0}}\right)$ is an expression related to primary photochemistry and $\Psi_{0} /\left(1-\Psi_{0}\right)$ is an expression related to electron transport (Oukarroum et al., 2007).

Modulated $\mathrm{Chl}$ a fluorescence: Modulated $\mathrm{Chl} \mathrm{a}$ fluorescence was measured 48 DAS by a fluorometer (FMS2, Hansatech Instruments, Kings Lynn, UK), and the fluorescence parameters were determined in light-adapted leaves. Calculations were made from the following: (1) the photochemical quenching coefficient $\left[\mathrm{qP}=\left(\mathrm{F}_{\mathrm{M}}{ }^{\prime}-\mathrm{F}_{\mathrm{S}}\right) /\left(\mathrm{F}_{\mathrm{M}}{ }^{\prime}-\mathrm{F}_{0}{ }^{\prime}\right)\right]$, (2) the efficiency of excitation capture by open PSII reaction centers $\left(F_{V}{ }^{\prime} / F_{M}{ }^{\prime}\right)$, and $(3)$ the actual PSIl efficiency $\left(\phi_{P S I I}\right)$. Fluorescence nomenclature was used according to van Kooten and Snel (1990). The pulse amplitude modulation (PAM) fluorescence technique obtains both qualitative and quantitative information on the organization and functioning of a plant photosynthetic apparatus by analysis of fast and slow Chl fluorescence induction kinetics.

Statistical analysis: Statistical analysis was conducted with the software package Statistica for Windows Version 6 (StatSoft Inc., 2300 East $14^{\text {th }}$ Street, Tulsa, OK, USA). The data were subjected to an analysis of variance (ANOVA). The differences in mean values between canola hybrids and salt treatment were compared by a Student's $t$-test.

\section{RESULTS}

Effects of salt stress on $\mathrm{Chl}$ content and growth: The hybrid type was the only factor that resulted in significant differences in $\mathrm{Chl}$ content. Hyola 401 and 43 were the hybrids with the highest and lowest $\mathrm{Chl}$ contents, respectively. However, there were no statistically significant differences in the $\mathrm{Chl}$ content caused by the salinity treatment stress within a given hybrid line (Figure $1 \mathrm{~A}$ ). The $\mathrm{Chl}$ content predominantly increased in Hyola 43 at $200 \mathrm{mM} \mathrm{NaCl}$, whereas the $\mathrm{Chl}$ content declined in Hyola 401 compared to control plants. However, these differences were not significant. The impact of salt stress on the leaf area (Figure 1B) also differed between hybrids. In Hyola 43 the leaf area declined at $50 \mathrm{mM}$, but the decrease was not significant. However, Hyola 61 had a significant decline at $200 \mathrm{mM}$ compared to 50 and $100 \mathrm{mM}$. In Hyola 401 there was no observed difference after salt treatment. In Hyola 420 there was a $47 \%$ reduction in leaf area in $200 \mathrm{mM} \mathrm{NaCl}$, and in Hyola 432 no difference was observed. Plant dry weight was reduced with increased $\mathrm{NaCl}$ concentration in all hybrids, but the reductions were more pronounced at $200 \mathrm{mM}$ (Figure 1C), especially in Hyola 61 (65\%), Hyola 420 (77\%) and Hyola 432 (63\%). When we compared the seed yield (Figure 1D) for hybrids without salinity (control plants), we observed that the hybrid Hyola 432 had the lowest yield $(0.44 \mathrm{~g}$ FW seed per plant), and Hyola 401 had the highest yield (1.47 g FW seed per plant). The seed yields decreased as the salinity level increased in all hybrids, except Hyola 432, which showed increases in seed yields at 50 and $100 \mathrm{mM} \mathrm{NaCl}$. The highest reductions in comparison with the control plants were observed in Hyola $43(87 \%)$ and Hyola 61 $(73 \%)$ at a salinity of $200 \mathrm{mM} \mathrm{NaCl}$. 

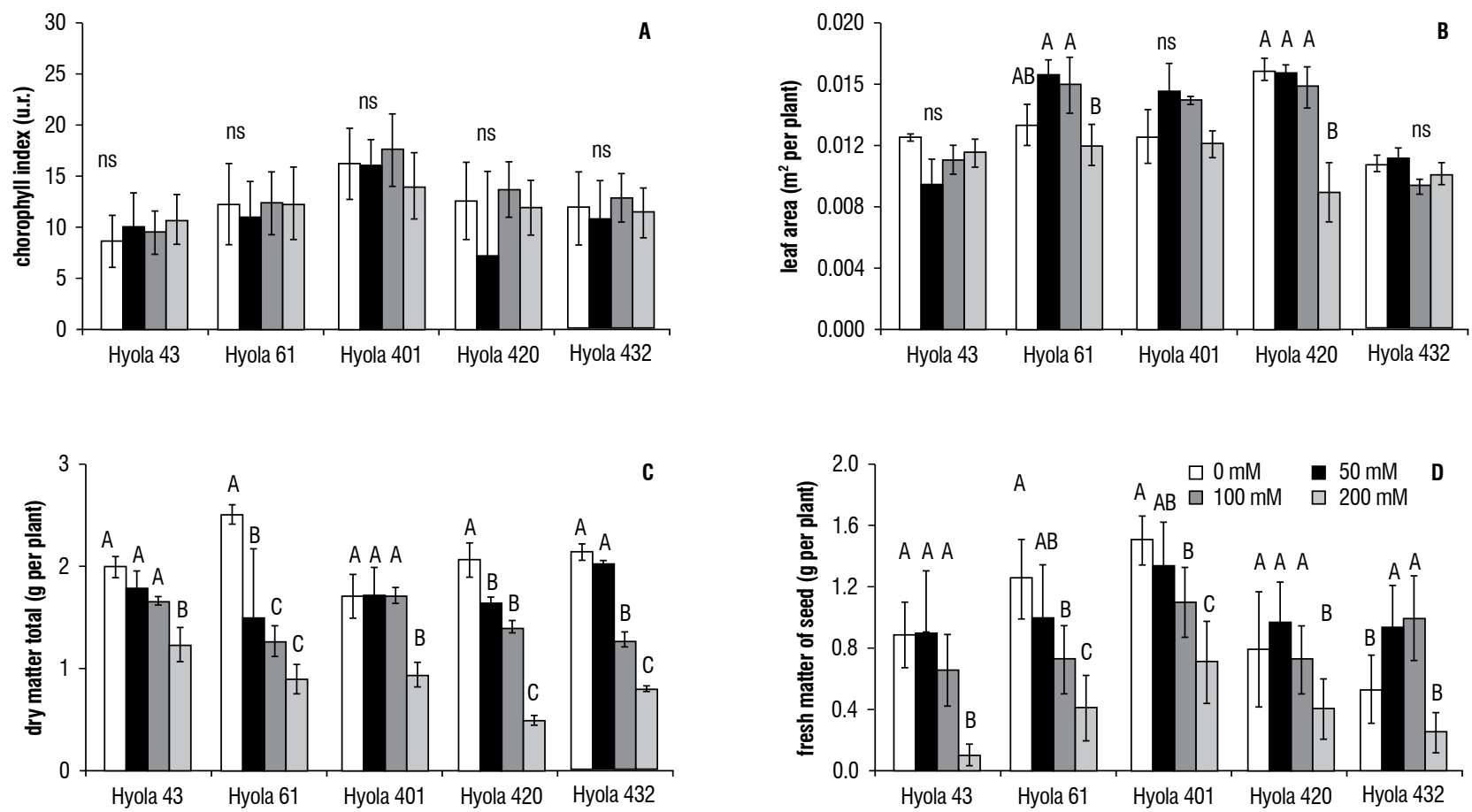

Figure 1. Chlorophyll content expressed as the "chlorophyll index" (a), leaf area in $\mathrm{m}^{2}$ per plant (b), total dry matter in g of dry matter per plant (c) and seed yield in $\mathrm{g}$ of fresh matter per plant (d) in different hybrids of canola subject to salt treatments. Each data point represents the average of eight plants \pm standard error. $\mathrm{ns}=$ non-significant at $p<0.05$. Different letters indicate significant differences among mean values within each Hybrid (Student t-test, $p \leq 0.05)$.

Effect of salt stress on Chl fluorescence: When plotted on a logarithmic time scale, the kinetics of fluorescence rise exhibited similar profiles, with distinct 0-J-I-P steps in all cases. The 0JIP transient represents the successive reduction of the electron acceptor pools of PSII (Strasser et al., 2000). Phase $\mathrm{J}$ reflects an accumulation of $Q_{A}{ }^{-} Q_{B}$ (Lazar, 2006). Phase I reflects an accumulation of $Q_{A}{ }^{-} Q_{B}{ }^{-}$, whereas phase $P$ reveals an accumulation of $Q_{A}{ }^{-} Q_{B}{ }^{2-}$ (Lazar, 2006). In Figure 2 we present the curves of chlorophyll fluorescence measured at $200 \mathrm{mM}$ of $\mathrm{NaCl}$ and control for different hybrids after 48 days of treatment, where we observed the typical curve 0JIP.

The maximal efficiency of PSIl photochemistry $\left(\phi_{P_{0}}\right)$, quantum yield of electron transport $\left(\phi_{\mathrm{E}_{0}}\right)$, quantum yield of dissipation of energy $\left(\phi_{D_{0}}\right)$ and yield of electron transport per trapped exciton $\left(\Psi_{0}\right)$ were altered by hybrids and salinity, but there were no significant differences in their interaction. The lowest values of $\phi_{P_{0}}, \Psi_{0}$, and $\phi_{E_{0}}$ were observed only at $200 \mathrm{mM}$ for all hybrids, although $\phi_{D_{0}}$ increased at this salt concentration. 

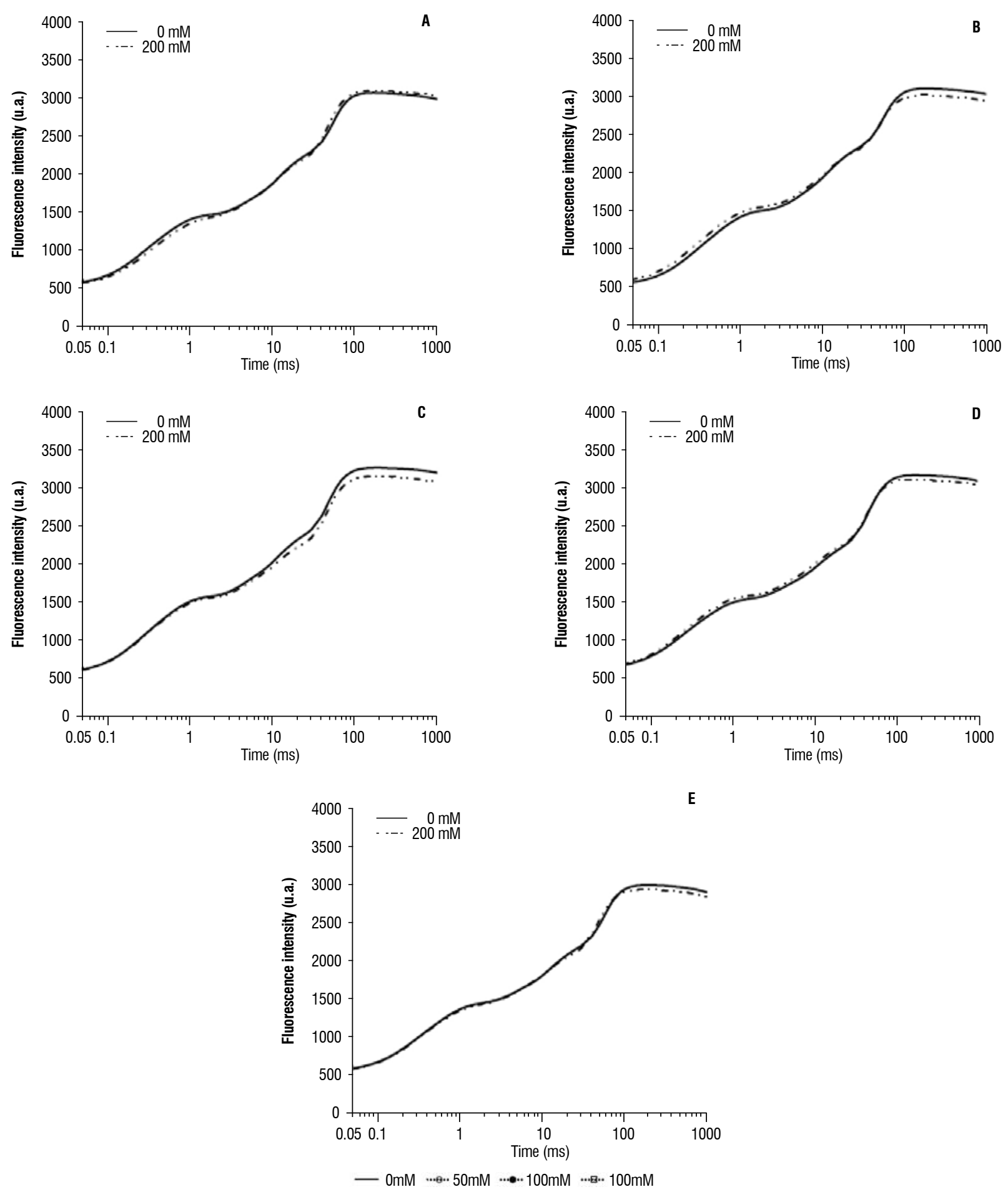

Figure 2. Curve of chlorophyll fluorescence measured at $200 \mathrm{mM}$ of NaCl and control for canola hybrids after 48 days of treatment. (a) Hyola 43, (b) Hyola 61, (c) Hyola 401, (d) Hyola 420. (e) Hyola 432.

The effect of salinity stress on some JIP-test parameters for each hybrid is shown in Figure 3. There was no large difference for hybrid and level $\mathrm{NaCl}$ to specific fluxes towards the RC: a) the $A B S / R C$ - the absorption flux per $\mathrm{RC}$, which indicates the apparent size of the antenna system of PSII, e.g. completely active quantity of absorbing 
chlorophyll per $\mathrm{RC} ; \mathrm{b}) \mathrm{TR}_{0} / \mathrm{RC}$ - the flux of trapping energy per $\mathrm{RC}$ in $\mathrm{t}=0$; c) $E T_{0} / \mathrm{RC}$ - flux of electron transport from $Q_{A}{ }^{-}$to $P Q$ per $R C$ in $t=0$. Only we observed that $D_{0} / R C$ ratio (flux of dissipated energy per $\mathrm{RC}$ in $\mathrm{t}=0$ ) increased at $200 \mathrm{mM}$ for Hyola 401 (Figure 3).
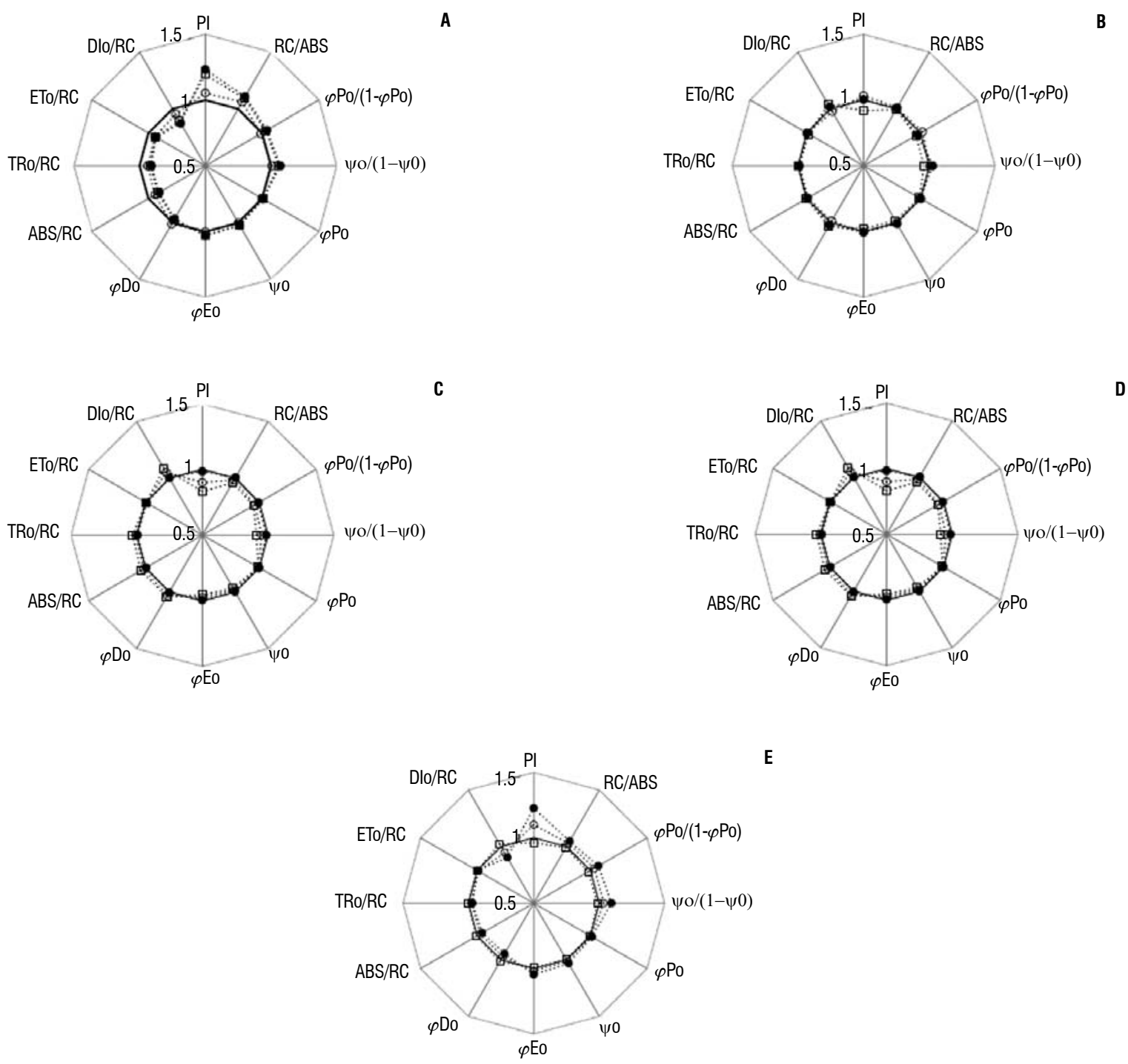

Figure 3. Derivation of the JIP-test parameters from Chl fluorescence induction curves for different canola hybrids (a) Hyola 43, (b) Hyola 61, (c) Hyola 401, (d) Hyola 420, (e) Hyola 432, subject to salt treatment relative to control (0 mM).

Using $\mathrm{Pl}_{\text {ABS-rel }}\left[\left(\mathrm{Pl}_{\mathrm{ABS} \text { stress }} / \mathrm{PI}_{\mathrm{ABS} \text { control }}\right)\right]$ as a measure of plant performance, differences in the response to salinity between the studied hybrids were revealed. The Performance Index relative $\left(\mathrm{Pl}_{\mathrm{ABS}-\text {-rel }}\right)$ decreased in Hyola 61 (8\%), Hyola 401 (27\%) and Hyola 420 (15\%), principally at $200 \mathrm{mM}$. The decline in $\mathrm{Pl}_{\text {ABs-rel }}$ observed in Hyola 401 and Hyola 420 was coupled with reductions in RC/ABS, $\phi_{P_{0}} /\left(1-\phi_{P_{0}}\right)$ and $\Psi_{o} /\left(1-\Psi_{0}\right)$ and increases in $\mathrm{DI}_{0} / \mathrm{RC}$. The $\mathrm{Pl}_{(\mathrm{ABS}) \text { )el }}$ increased in Hyola 43 at 100 and $200 \mathrm{mM}$ and in Hyola 432 at 50 and $100 \mathrm{mM}$.

The Figure 4 shows the correlation of the log relative Performance Index [log $\left.\mathrm{Pl}_{\mathrm{ABS}-\mathrm{rel}}\right]$ : (A) log of the relative reaction centers per chlorophyll $\left[\log (\mathrm{RC} / \mathrm{ABS})_{\mathrm{rel}}\right]$, (B) $\log$ of the relative efficiency of primary photochemical $\left[\log \left(\phi_{\mathrm{P}_{0}} / 1\right.\right.$ - $\left.\left.\phi_{P_{0}}\right)_{r e l}\right],(C) \log$ of the relative efficiency of the conversion 
of excitation energy to electron transport $\left[\log \left(\Psi_{0} / 1-\Psi_{0}\right)_{\text {rel }}\right]$ and (D) $\log$ of the relative electron transport activity $\left[\log \left(\phi_{\mathrm{E} 0}\right)\right.$ rel]. All log functions were linear with correlation coefficients
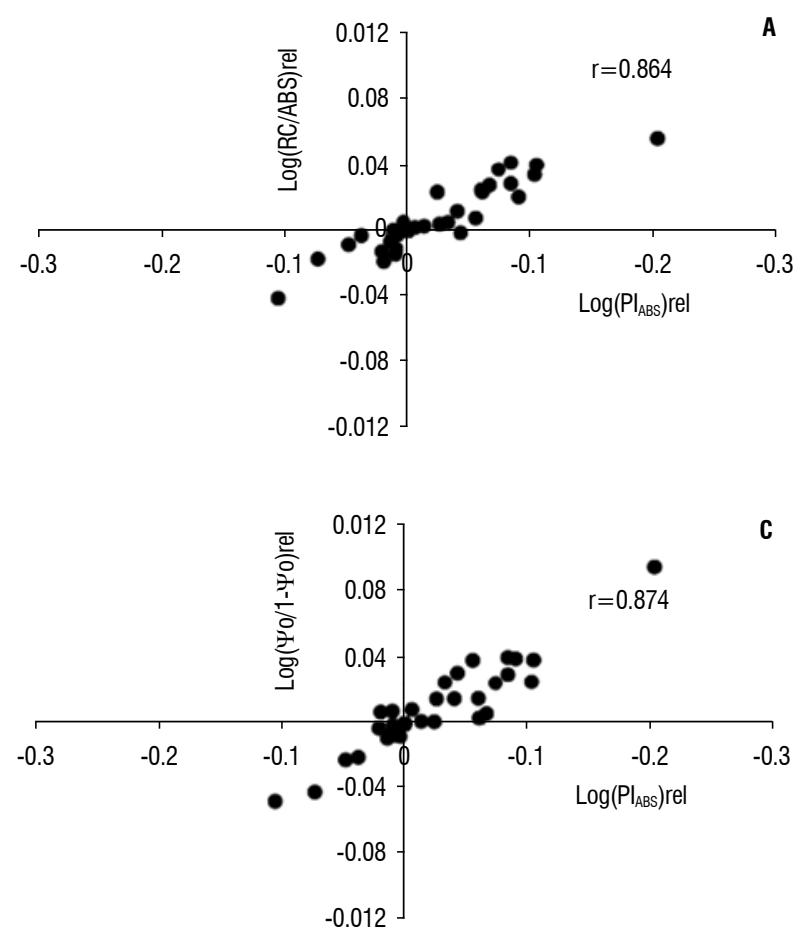

of higher than 0.86; however the relationship between $\left[\log \left(\mathrm{Pl}_{\mathrm{ABS}-\mathrm{rel}}\right]\right.$ and $\left[\log \left(\phi_{\mathrm{E} 0}\right)_{\text {rel }}\right]$ had the highest correlation coefficient (0.948).
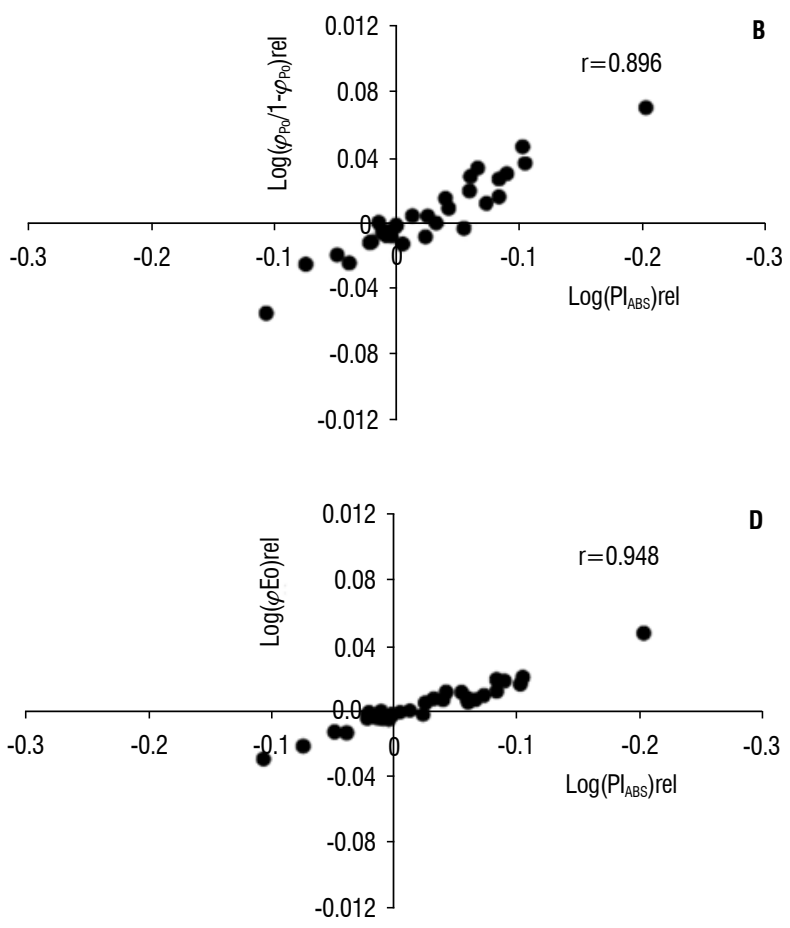

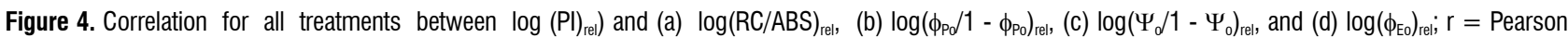
correlation coefficient.

Table 2. The efficiency of excitation capture by open PSII reaction centers $\left(\mathrm{F}_{\mathrm{v}}{ }^{\prime} / \mathrm{F}_{\mathrm{M}}{ }^{\prime}\right)$, the actual PSII efficiency $\left(\phi_{\mathrm{PSII}}\right)$ and photochemical extinction coefficient $(\mathrm{qP})$ in different hybrids of canola cultivated with salt treatments.

\begin{tabular}{|c|c|c|c|c|c|c|}
\hline & \multicolumn{6}{|c|}{$\mathrm{NaCl}(\mathrm{mM})$} \\
\hline \multirow{7}{*}{$F_{v}^{\prime} / F_{M}^{\prime}$} & & 0 & 50 & 100 & 200 & Means \\
\hline & Hyola 43 & $0.743^{*}$ & 0.746 & 0.780 & 0.772 & $0.760 \mathrm{~b}$ \\
\hline & Hyola 61 & 0.771 & 0.742 & 0.780 & 0.764 & $0.763 b$ \\
\hline & Hyola 401 & 0.701 & 0.758 & 0.758 & 0.786 & $0.750 \mathrm{bc}$ \\
\hline & Hyola 420 & 0.722 & 0.691 & 0.769 & 0.756 & $0.734 \mathrm{c}$ \\
\hline & Hyola 432 & 0.780 & 0.799 & 0.802 & 0.794 & $0.793 \mathrm{a}$ \\
\hline & Means & $0.743 b^{\star \star}$ & $0.746 \mathrm{~b}$ & $0.777 \mathrm{a}$ & \multicolumn{2}{|c|}{$0.774 \mathrm{a}$} \\
\hline \multirow{6}{*}{$\phi_{\mathrm{PSII}}$} & Hyola 43 & 0.684 & 0.713 & 0.754 & 0.744 & 0.724 \\
\hline & Hyola 61 & 0.729 & 0.711 & 0.732 & 0.714 & 0.721 \\
\hline & Hyola 401 & 0.638 & 0.692 & 0.729 & 0.757 & 0.704 \\
\hline & Hyola 420 & 0.672 & 0.621 & 0.748 & 0.730 & 0.693 \\
\hline & Hyola 432 & 0.754 & 0.776 & 0.776 & 0.769 & 0.769 \\
\hline & Means & $0.695 \mathrm{~b}$ & $0.702 \mathrm{~b}$ & $0.747 \mathrm{a}$ & \multicolumn{2}{|c|}{$0.742 \mathrm{a}$} \\
\hline \multirow{6}{*}{$q P$} & Hyola 43 & 0.913 & 0.953 & 0.967 & 0.963 & 0.949 \\
\hline & Hyola 61 & 0.946 & 0.957 & 0.939 & 0.932 & 0.943 \\
\hline & Hyola 401 & 0.901 & 0.911 & 0.961 & 0.962 & 0.934 \\
\hline & Hyola 420 & 0.929 & 0.898 & 0.973 & 0.966 & 0.942 \\
\hline & Hyola 432 & 0.967 & 0.971 & 0.968 & 0.968 & 0.968 \\
\hline & Means & 0.931 & 0.938 & 0.961 & 0.958 & \\
\hline
\end{tabular}

${ }^{\star}$ means of ten measurements;

**Different letters indicate significant differences among mean values within each Hybrid (Student t-test, $p \leq 0.05$ ). 
The effect of salt stress treatments on the $\mathrm{F}_{\mathrm{V}}{ }^{\prime} / \mathrm{F}_{\mathrm{M}}{ }^{\prime}, \phi_{\mathrm{PSII}}$ and $\mathrm{qP}$ in fully expanded leaves is shown in Table 2. The Hyola 432 hybrid showed the highest values for the $F_{v}{ }^{\prime} / F_{M}$ ' ratio and $\phi_{P S I I}$, and Hyola 420 had the lowest $F_{V}{ }^{\prime} / F_{M}$ ' ratio. The highest values of $F_{\mathrm{V}}{ }^{\prime} / \mathrm{F}_{\mathrm{M}}{ }^{\prime}$ and $\phi_{\mathrm{PSII}}$ were observed with 100 and $200 \mathrm{mM} \mathrm{NaCl}$. There were no significant differences in the quenching photochemical (qP).

\section{DISCUSSION}

The leaf area, total dry matter and seed yields were affected by salinity stress in canola hybrids, principally at 200 $\mathrm{mM}$; however there were differences in sensitivity between the hybrids (Figure 1). The hybrids Hyola 43 and Hyola 432 were less affected by salinity. Studies on the effects of salinity on carbon assimilation in plants could enable a more comprehensive understanding of their productivity and growth (Chaves et al., 2009). However, the studies show that photosynthetic responses to salinity are highly complex and have some limitations when measuring at different sites on the cell or leaf and at different developmental stages. It is well established that the main effect of salt stress is to decrease photosynthesis, which reduces $\mathrm{CO}_{2}$ fixation rates and plant growth. Maricle et al. (2007) concluded that salinity decreased $\mathrm{CO}_{2}$ fixation, but the processes responsible for harvesting solar energy are largely unaffected by increasing salinity in estuarine grasses. While the use of this energy changes with increasing irradiance and salinity, they suggest that there is no strong relationship between fluorescence parameters and salt sensitivity in this species. Our results show that different $B$. napus genotypes have different levels of susceptibly to salt stress and that the photochemical process can be altered by high salt.

In the present study, we did not find a simple relationship between the growth and fluorescence parameters because the growth was affected by all salt levels, and the fluorescence parameters were only altered in high salinity. Our results showed a slight difference in the maximum yield of primary photochemistry of PSII $\left(\phi_{P_{0}}\right)$ observed only at $200 \mathrm{mM}$ for all hybrids. Similar results were obtained in the yield of electron transport per trapped exciton $\left(\Psi_{0}\right)$ and for the quantum yield of electron transport $\left(\phi_{\mathrm{E}_{0}}\right)$ as well as an increase for the quantum yield of dissipation $\left(\phi_{D_{0}}\right)$. The salinity showed little effect in the light-adapted state fluorescence parameters, $F_{\mathrm{V}}{ }^{\prime} / \mathrm{F}_{\mathrm{M}}{ }^{\prime}$ and $\phi_{\mathrm{PSII}}$, and no affect on the $\mathrm{qP}$ (Table 2).
To better evaluate the effects of salt stress on the primary photochemistry of PSII, we examined the absorption flux (ABS), trapping flux (TR) and electron transport flux (ET) per PSIl reaction center $(\mathrm{RC})$, i.e. $A B S / R C, T_{0} / R C, E_{0} / R C$. Our results show that these parameters did not change significantly at $0-200 \mathrm{mM}$. Our results show that there was no significant change in the trapping flux per PSII reaction center $\left(\mathrm{TR}_{0} / \mathrm{RC}\right)$ in salt-stressed plants. $\mathrm{TR}_{0} / \mathrm{RC}$ represents the maximum rate of reduction of $Q_{A}$ (Strasser et al., 2000). No change in $T R_{0} / R C$ in salt-stressed plants proposes that the high conversion efficiency of excitation energy was preserved. According to the results in this study, it is suggested that through a down-regulation of PSII reaction centers and a shift of excitation energy transfer to PSI, the PSII apparatus was thus protected from further excess excitation energy by increased in $\mathrm{DI}_{0} / \mathrm{RC}$.

One of the parameters used to analyze the response of the plant to stress is the $\mathrm{Pl}_{\mathrm{ABS}}$. In previous studies, $\mathrm{Pl}_{\mathrm{ABS}}$ was used to estimate plant vitality in response to different environmental stresses to create vitality groups (Strasser et al., 2000). The decrease of the $\mathrm{Pl}_{\mathrm{ABS} \text {-rel }}$ in response to salinity stress in Hyola 61, Hyola 401 and Hyola 420 was mainly due to a decrease of the photochemical efficiency of photosynthetic electron transport and an increase of $\mathrm{DI}_{0} / \mathrm{RC}$ in high salt. The increase of the $\mathrm{Pl}_{\mathrm{ABS}-\text {-rel }}$ in response to salinity stress in Hyola 432 was principally due to an increase in the efficiency of primary photochemistry and photochemical efficiency of photosynthetic electron transport associated with a decreased $\mathrm{DI}_{0} / \mathrm{RC}$.

Linear correlations were observed between the log functions of the Performance Index, the log of the three independent components of $\mathrm{Pl}_{\mathrm{ABS}}$ and the log of the relative electron transport activity. The linear correlation observed between the two log functions of the Performance Index and the electron transport activity indicates that changes in $\phi_{E_{0}}$ were responsible for most of the change in the multiparametric expression of $\mathrm{PI}_{A B S}$ in the case of salt stress, but additional alterations in the components of $\mathrm{Pl}_{\mathrm{ABS}}$ cannot be ruled out. When Oukarroum et al. (2007) studied drought and re-watering on 10 varieties of barley (Hordeum vulgare L.), they described the same occurrence. Misra et al. (2001) studied salt and ion effects on the photosynthetic system that showed the same linearity between these two log functions, and they proposed that this analysis allowed them 
to determine the susceptibly of the different genotypes to salt or ion stress. The same correlation was used to estimate the relative health of Platanus acerfolia L. trees in a quality assessment of urban trees (Hermans et al., 2003). Thus, we conclude that the decrease in growth can not be attributed only the variation in the fluorescence parameters, but the salt effect on fluorescence parameters is mainly observed in high salt. The response to salt stress is dependent on the genotype, and the Performance Index can be used to distinguish the level of tolerance to stress.

Acknowledgement: This work was supported by CNPq (Conselho Nacional de Desenvolvimento Científico e Tecnológico), Secretaria de Desenvolvimento Tecnológico e Inovação do Ministério de Ciência e Tecnologia (MCT) and CAPES (Coordenação de Aperfeiçoamento de Pessoal de Nivel Superior). The authors thank the "Celema Alimentos S/A" for supplying the seeds.

\section{REFERENCES}

Azevedo Neto AD, Prisco JT, Enéas-Filho J, Lacerda CF, Silva JV, da Costa PHA, Gomes-Filho E (2004) Effects of salt stress on plant growth, stomatal response and solute accumulation of different maize genotypes. Braz. J. Plant Physiol.,16: 31-38.

Abreu CEB, Prisco JT, Nogueira ARC, Bezerra MA, Lacerda CFL, Gomes-Filho, $\mathrm{E}$ (2008) Physiological and biochemical changes occurring in dwarf-cashew seedlings subjected to salt stress. Braz. J. Plant Physiol. 20:105-118.

Cassol D, Silva FSP, Falqueto AR, Bacarin MA (2008) An evaluation of nondestructive methods to estimate total chlorophyll content. Photosynthetica 46:634-636.

Chaves MM, Flexas J, Pinheiro C (2009) Photosynthesis under drought and salt stress; regulation mechanisms from whole plant to cell. Ann. Bot 103:551-560.

Eyidogan F, Tufan OM (2007) Effect of salinity on antioxidant responses of chickpea seedlings. Acta-Physiol. Plant. 29:485-493.

Flexas J, Bota J, Loreto F, Cornic G, Sharkey TD (2004) Diffusive and metabolic limitations to photosynthesis under drought and salinity in $C_{3}$ plants. Plant Biol. 6:269-279.

Hermans C, Smeyers M, Rodriguez RM, Eyletters M, Strasser RJ, Delhaye JP (2003) Quality assessment of urban trees: a comparative study of physiological characterization, airborne imaging and on site fluorescence monitoring by the 0JIP-test. J. Plant Physiol. 160:81-90.

Hoagland D, Arnon DI (1950) The water culture method for growing plants without soil. California Agriculture Experimental Station Circular. 347 p.

Kris-Etherton PM, Taylor DS, Yu-Poth S, Huth P, Moriarty K, Fishell V, Hargrove RL, Zhao G, Etherton TD (2000) Polyunsaturated fatty acids in the food chain in the United States. Am. J. Clin. Nutr.71:179S-188S.

Lazár D (2006) The polyphasic chlorophyll a fluorescence rise measured under high intensity of exciting light. Funct. Plant Biol.33:9-30.
Maia, JM, Voigt EL, Macêdo CEC, Ferreira-Silva SL, Silveira JAG (2010) Salt-induced changes in antioxidative enzyme activities in root tissues do not account for the differential salt tolerance of two cowpea cultivars. Braz. J. Plant Physiol., 22: 113-122.

Maricle BR, Lee RW, Hellquist CE, Kiirats 0, Edwards GE (2007) Effects of salinity on chlorophyll fluorescence and $\mathrm{CO}_{2}$ fixation in $\mathrm{C}_{4}$ estuarine grasses. Photosynthetica 45:433-440.

Misra AN, Srivastava A, Strasser RJ (2001) Utilization of fast chlorophyll a fluorescence technique in assessing the salt/ion sensitivity of mung bean and Brassica seedlings. J. Plant Physiol. 158: 1173-1181.

Munns R, Tester M (2008) Mechanisms of salinity tolerance. Annu Rev Plant Biol. 59:651-681.

Oukarroum A, Madidi SE, Schansker G, Strasser RJ, (2007) Probing the responses of barley cultivars (Hordeum vulgare L.) by chlorophyll a fluorescence OLKJIP under drought stress and re-watering. Environ. Exp. Bot. 60:438-446.

Oukarroum A, Strasser RJ (2004) Phenotyping of dark and light adapted barley plants by the fast chlorophyll a fluorescence rise OJIP. S. Afr. J. Bot 70:277-283.

Panda D, Dash PK, Dhal NK, Rout NC (2006) Chlorophyll fluorescence parameters and chlorophyll content in mangrove species grown in different salinity. Gen. Appl. Plant Physiol. 32:175-180.

Percival GC, Fraser GA, Oxenham G (2003) Foliar salt tolerance of acer genotypes using chlorophyll fluorescence. J. Arboricult. 29:61-65.

Qin J, Dong WY, He KN, Chen J, Liu J, Wang ZL (2010) Physiological responses to salinity in Silver buffaloberry (Shepherdia argentea) introduced to Qinghai high-cold and saline area China. Photosynthetica 48:51-58.

Redondo-Gómez S, Mateos-Naranjo E, Davy AJ, Fernández-Muñoz F, Castellanos EM, Luque T, Figueroa ME (2007) Growth and Photosynthetic Responses to Salinity of the Salt-marsh Shrub Atriplex portulacoides. Ann. Bot. 100:555-563.

Strasser BJ, Strasser RJ (1995) Measuring fast fluorescence transients to address environmental questions: The JIP-test. In: Mathis P (ed) Photosynthesis: From light to biosphere. vol. 5, pp. 977-980. Kluwer Academic Publishers, Dordrecht, The Netherlands.

Strasser RJ, Srivastava A, Tsimilli-Michael M (2000) The fluorescence transient as a tool to characterize and screen photosynthetic samples, In: Yunus M, Pathre U, Mohanty P (eds), Probing photosynthesis: Mechanism, regulation and adaptation, pp. 443-480. Taylor and Francis, London, UK,

Strasser RJ, Tsimilli-Michael M, Srivastava A (2004) Analysis of the Chlorophyll a Fluorescence Transient. In: Papageorgiou GC, Govindjee (eds), Chlorophyll fluorescence: A Signature of Photosynthesis, Advances in Photosynthesis and Respiration Series vol 19, pp 321-362. Kluwer Academic Publishers, Rotterdam, The Netherlands.

Tavakkoli E, Rengasamy P, McDonald GK (2010) High concentrations of $\mathrm{Na}^{+}$ and $\mathrm{Cl}^{-}$ions in soil solution have simultaneous detrimental effects on growth of faba bean under salinity stress. . J. Exp. Bot. 61:4449-4459

van Kooten 0, Snel JFH (1990) The use of chlorophyll fluorescence nomenclature in plant stress physiology. Photosynth. Res. 25:147-150.

Zhu JK (2001) Plant salt tolerance. Trends Plant Sci. 6:66-71

Zurita JL, Roncel M, Aguilar M, Ortega JM (2005) A thermoluminescence study of photosystem II back electron transfer reactions in rice leaveseffects of salt stress. Photosynth. Res. 84:131-137. 